\title{
TOPOSSEQUÊNCIA DE SOLOS NA ILHA DA TRINDADE, ATLÂNTICO SUL ${ }^{(1)}$
}

\author{
Eliane de Paula Clemente ${ }^{(2)}$, Carlos Ernesto G.R. Schaefer ${ }^{(3)}$, Fábio \\ Soares Oliveira ${ }^{(4)}$, Manoel Ricardo Albuquerque Filho ${ }^{(2)}$, Ruy Válka \\ Alves $^{(5)}$, Mariana Médice Firme Sá( ${ }^{(6)}$, Vander de Freitas Melo ${ }^{(7)} \&$ \\ Guilherme Resende Corrêa ${ }^{(8)}$
}

\begin{abstract}
RESUMO
As ilhas oceânicas, como ambientes sui generis no planeta, têm despertado, cada vez mais, o interesse da comunidade científica em virtude de sua importância ambiental. Este trabalho teve por objetivo estudar os principais solos de ocorrência da Ilha da Trindade, enfatizando suas características químicas e físicas nos diferentes estratos ambientais de ocorrência. Buscou-se melhor entendimento das relações pedogeomorfológicas, permitindo um esboço preliminar da identificação dos solos ao longo da expressiva variação topográfica reinante na área de estudo. Ao longo de uma topossequência, foram coletados 10 perfis representativos dos diferentes pedoambientes, resultantes de variações litológicas, topográficas e de cobertura vegetal, muitas das quais covariantes. Foram realizadas análises físicas e químicas de todos os horizontes dos perfis coletados. A diversidade de solos na Ilha da Trindade pode ser relacionada com as variações do material de origem e da posição topográfica. De maneira geral, os solos apresentam peculiaridades que os tornam "endêmicos". A maioria possui alta fertilidade natural, grau de intemperismo pouco acentuado e valores muito elevados de $\mathrm{P}$ e Ca que parecem relacionados com atividade da avifauna. Na face sul da ilha, mais fria e úmida, vales estreitos e encostas íngremes abrigam vegetação mais exuberante de
\end{abstract}

(1) Parte da Tese de Doutorado da primeira autora publicada em setembro de 2006, com financiamento do CNPq. Recebido para publicação em junho de 2008 e aprovado em maio de 2009.

(2) Pesquisadora da Embrapa Solos - CNPS. Rua Jardim Botânico 1024 CEP 22460-000 Rio de Janeiro (RJ). E-mail: eliane@cnps.embrapa.br

${ }^{(3)}$ Professor Associado do Departamento de Solos, Universidade Federal de Viçosa - UFV. Av. Peter Henry Rolfs s/n, CEP 36570000 Viçosa (MG). Bolsista CNPq. E-mail: carlos.schaefer@ufv.br

(4) Doutorando no Departamento de Geologia, Universidade Federal de Ouro Preto - UFOP. R. Diogo de Vasconcelos 122, CEP 35400-000 Ouro Preto (MG). E-mail: fabiosoares@ufv.br

(5) Professor Adjunto, Fórum de Ciência e Cultura, Museu Nacional. Universidade Federal do Rio de Janeiro - UFRJ. Av. Pedro Calmon 550, Cidade Universitária, CEP 21941-901 Rio de Janeiro (RJ). E-mail: ruyvalka@yahoo.com

${ }^{(6)}$ Mestranda, Departamento de Solos, Universidade Federal de Viçosa - UFV. Av. Peter Henry Rolfs s/n, CEP 36570-000 Viçosa (MG). Bolsista CNPq. E-mail: mariana_medice@hotmail.com

(7) Professor Adjunto do Departamento de Solos, Universidade Federal do Paraná - UFPR. Rua dos Funcionários 1540, CEP 80035-050 Curitiba (PR). Bolsista CNPq. E-mail: vanderfm@ufpr.br

${ }^{(8)}$ Doutorando do Departamento de Solos, Universidade Federal de Viçosa - UFV. Av. Peter Henry Rolfs s/n, CEP $36570-000$ Viçosa (MG). Bolsista CNPq. E-mail: guilhermeudi@yahoo.com.br 


\begin{abstract}
samambaias gigantes, com acúmulo em ambiente escarpado, de matéria orgânica fíbrica mesmo em declives acentuados, formando Organossolos em ambientes atípicos. Os solos de locais com altitude superior a $400 \mathrm{~m}$ são mais ácidos e pobres em nutrientes, mas com teor de $P$ muito elevado em função de aportes da avifauna. Na face norte da ilha, em cotas mais baixas, predominam condições semiáridas ou tropicais secas, e os solos são mais rasos, ricos em nutrientes e muito mais erodidos, com predomínio de Neossolos Litólicos e Regolíticos. Há diversas particularidades nos solos da Ilha da Trindade que os tornam difíceis de enquadramento no Sistema Brasileiro de Classificação de Solos, carecendo de adaptações em diversos níveis categóricos.
\end{abstract}

Termos de indexação: ilha da Trindade, solos endêmicos, rochas vulcânicas, Atlântico sul.

\title{
SUMMARY: TOPOSSEQUENCE OF SOILS ON THE TRINDADE ISLAND IN THE BRAZILIAN SOUTH ATLANTIC
}

The Brazilian Oceanic islands are unique environments which have received increasing attention from the scientific community due to their environmental importance. This study aimed to provide a first characterization of soils of the Trindade Island, considering mainly the chemical and physical properties in the different geoenvironments. Another objective was to contribute to a deeper undestanding of the pedogeomorphological relationships, allowing a preliminary identification of soils along a typical toposequence. A total of 10 soil profiles representing all geoenvironments were sampled. These soils were the result of lithological, topographical and vegetation influences, frequently in close association. Soil chemical, morphological and physical analyses were performed and the results indicate the ocurrence of unique features that suggest an endemic character. The pedodiversity on Trindade is primarily related to the parent material and topographical variations. Soils generally have high fertility, particularly in terms of $C a$ and $P$ contents associated with bird excreta inputs. On the southern side of the island, with a cooler and wetter climate, narrow valleys and steep slopes shelter a more exuberant vegetation of giant ferns, with accumulation of fibrous organic material even on steep slopes, forming atypical Histosols. Soils at an altitude of over $400 \mathrm{~m}$ are more acid and nutrient-poor, but P contents are still very high, which was attributed to bird activity. On the northern side of the island, semi-arid to tropical dry climates prevail, and soils are shallower, nutrient-rich and highly eroded, with dominance of Litholic or Regolitic Neosols. Some pedological features of Trindade soils prevent an appropriate fitting by the Brazilian Soil Classification System, calling for adaptations at various classification levels for an adequate classification.

Index terms: Trindade Island, endemic soils, volcanic rocks, South Atlantic Ocean.

\section{INTRODUÇÃO}

As ilhas oceânicas são ambientes únicos do planeta devido ao seu isolamento geográfico, e têm despertado, cada vez mais, o interesse da comunidade científica brasileira. Se outrora foram alvos de expedições estritamente exploratórias, cujo objetivo central era o reconhecimento de novas áreas, agora representam verdadeiros territórios de estudos da biodiversidade e manutenção de ecossistemas únicos. O isolamento geográfico associado às condições particulares de formação geológica e evolução biológica é responsável pela indução de um conjunto de fatores bióticos e abióticos bastante particulares, como alto grau de endemismo e participação ativa na reprodução e alimentação de diversos organismos marinhos e terrestres, como as aves migratórias. Além disso, representam áreas estratégicas na organização política e gestão das atividades marítimas de diversos países, muitas vezes sendo ocupadas por bases militares ou mesmo por postos avançados de vigilância. No Brasil, devido à extensão do seu litoral e área oceânica adjacente, são encontrados diversos conjuntos de ilhas e ilhotas, destacando-se cinco arquipélagos principais: Fernando de Noronha; São Pedro e São Paulo; Trindade e Martin Vaz; Abrolhos; e Atol das Rocas. Com exceção do primeiro, todos os outros permanecem como áreas militares e, ou, de pesquisas, sem autorização para o desenvolvimento de atividades turísticas.

Das pesquisas realizadas nas ilhas oceânicas brasileiras até o momento, prevalecem os estudos que procuraram retratar flora e fauna marinhas, sendo escassos trabalhos em ambientes terrestres. Desses, destacam-se os estudos desenvolvidos por Almeida (1961, 1965) e Campos et al. (2005), relativos à geologia, 
e de Alves $(1998,2006)$ sobre a botânica. Outras contribuições pertinentes à geologia podem ser obtidas em Milet-Mureau (1797), Prior (1900), Veltheim (1950), Soares (1964), Cordani (1970) e Weaver (1990). Em relação aos solos, as pesquisas tornam-se ainda mais escassas, sendo conhecidos apenas os trabalhos de Batistela (1993) e Marques (2004, 2007a,b) acerca dos solos de Fernando de Noronha, Paul Vageler (Veltheim, 1950) com observações preliminares e gerais sobre os solos de Trindade e, mais recentemente, Clemente et al. (2006), que aprofundam os estudos pedológicos naquela ilha. Tal lacuna de conhecimento, muitas vezes responsável pelo manejo inadequado desses ambientes, indica um desafio a ser superado: desbravar tais sentinelas do oceano sob uma perspectiva pedológica e oportunizar a geração de um conjunto de informações sobre os solos que poderão subsidiar medidas intervencionistas, sejam elas de recuperação e, ou, preservação.

Em geral, a maior parte dos estudos sobre solos de ilhas oceânicas (Cardoso, 1958; Nunes, 1962; Faria, 1974; Lima, 2003; Marques, 2004, 2007a,b) tem evidenciado uma associação entre as características dos solos e o material de origem, majoritariamente de natureza vulcânica. Como resultado, observa-se solos altamente diferenciados em relação àqueles encontrados nos continentes, reconhecidos nos preceitos de Bockheim (2005) como endêmicos. Neste contexto, insere-se a Ilha da Trindade.

No decorrer dos cinco séculos desde que foi descoberta, a Ilha da Trindade permaneceu desabitada por longos períodos, o que deu ensejo a invasões estrangeiras esporádicas. Por sua grande distância da costa, dificuldade de desembarque e acesso exclusivamente por mar, não oferece condições para o turismo, mas é um local excepcional para investigações científicas, pelo extremo isolamento do continente. Conforme destacado por Alves (1998), são necessários estudos de solos e melhor detalhamento dos geoambientes para permitir um planejamento de ações visando à recuperação ambiental da ilha, severamente destruída com imensas áreas completamente erodidas.

Trindade foi visitada por exploradores e cientistas participantes das expedições de James Cook em 1775, James Ross em 1839, do navio Challenger em 1876 e de La Pérouse em 1887. Prior (1900), examinando o material geológico coletado pela expedição de James Ross, destacou a natureza vulcânica da Ilha e sua semelhança com Fernando de Noronha. Da expedição brasileira de João Alberto, em 1950, os geólogos Andrade Ramos e Veltheim, e o pedólogo Paul Vageler, registraram as primeiras impressões geológicas e pedológicas (Veltheim, 1950), enquanto Soares (1964) publicou uma síntese dos conhecimentos relativos à geologia e geografia de Trindade. Cordani (1970) divulgou o resultado de 36 datações pelo método K Ar de rochas que coletou, dando apoio aos trabalhos de Almeida (1965). Weaver (1990) realizou um estudo geoquímico de rochas das coleções do Museu Britânico, além dos trabalhos já referenciados de Almeida (1961 e 2000) sobre a geologia da Ilha. De modo geral, a despeito da imensa importância estratégica que possui e do extremo isolamento biogeográfico, Trindade permaneceu um campo aberto aos estudos ambientais.

A partir de tal contexto, este trabalho objetivou estudar em detalhes os principais solos da Ilha da Trindade, enfatizando seus atributos químicos e físicos nos principais estratos ambientais, bem como buscar maior entendimento das relações pedogeomorfológicas e ecológicas que permitam um esboço preliminar da identificação dos solos ao longo da expressiva variação topográfica reinante na ilha. Objetivou-se, ainda, contribuir para a classificação e o enquadramento dos solos estudados no SiBCS, a partir da caracterização dos solos de ocorrência mais comum na ilha, mas que possuem peculiaridades importantes comparados aos solos da porção continental brasileira, ressaltando características pedológicas endêmicas que se traduzem na dificuldade de enquadramento.

\section{MATERIAL E MÉTODOS}

\section{Caracterização da área de estudo}

A ilha está distante cerca de $1.140 \mathrm{~km}$ da costa no paralelo de Vitória, situada a $20^{\circ} 30$ ' $\mathrm{S}$ e $29^{\circ} 18^{\prime}$ WG (coordenadas centrais). O isolamento na superfície oceânica da Ilha da Trindade não deixa entrever que é parte de uma grande cadeia vulcânica submarina orientada leste-oeste, conhecido como lineamento Vitória-Trindade. A Ilha constitui um corpo vulcânico apoiado no assoalho oceânico, a quase $5.500 \mathrm{~m}$ de profundidade. Outros edifícios vulcânicos ao longo do lineamento, situados entre Trindade-Martim Vaz e a costa do estado do Espírito Santo, foram inteiramente arrasados pela erosão marinha na última glaciação, nivelados a menos de $100 \mathrm{~m}$ de profundidade. Hoje, constituem-se guyots, usualmente chamados bancos submarinos. Trindade, por ter sua atividade vulcânica persistido por mais tempo, ainda se eleva acima da superfície oceânica (Almeida, 2000). A ilha é resultado de cinco formações geológicas, denominadas Complexo de Trindade, como pode ser visto no trabalho de Almeida (1961).

Em muitas praias da ilha são encontrados arenitos calcíferos (calcarenitos), que consistem, principalmente, de fragmentos de algas calcáreas com fragmentos minerais bastante instáveis, como a sanidina. O componente detrítico desses arenitos é idêntico aos das areias das praias atuais da ilha, também semelhante ao componente detrítico dos beach rocks calcareníticos formados. Esses calcarenitos constituem plataformas planas restritas em áreas localizadas a 2-3 m acima do nível do mar, sendo muito semelhantes aos descritos em Fernando de Noronha por Almeida (1965). As feições eólicas são representadas por dunas de areias 
carbonáticas, que, sob ação dos ventos sudeste, movemse em direção às partes elevadas da ilha (Schobbenhaus et al., 1984). Conforme observações de campo, grande parte das areias de praias atuais são produtos de retrabalhamento erosivo das plataformas de calcarenitos que circundam a ilha (Schaefer et al., 2005).

\section{Descrição e coleta dos solos}

A caracterização dos solos na Ilha da Trindade foi realizada ao longo de uma topossequência abragendo toda a face norte da Ilha e parte da face sul. Tais coletas foram feitas em trabalho de campo realizado em 2003. Após intenso reconhecimento da área, com notáveis dificuldades logísticas, e determinada a localização da topossequência, foram selecionados solos resultantes de variações litológicas, topográficas e de cobertura vegetal. Em cada ponto, foi descrito e coletado um perfil de solo representativo, compreendendo todos os horizontes pedogenéticos, sendo também coletadas amostras compostas da superfície e da vegetação para análises comparativas. A descrição de campo foi realizada segundo o Manual de Descrição e Coleta de Solos no Campo (Lemos \& Santos, 1996). As amostras superficiais dos solos em cada ponto foram obtidas a partir de mistura homogênea de 20 subamostras de $500 \mathrm{~g}$ cada, quarteadas e uniformizadas antes do envio ao laboratório. Os solos foram classificados segundo o Sistema Brasileiro de Classificação de Solos (Embrapa, 2006).

\section{Análises físicas}

A granulometria dos solos foi obtida por dispersão com $\mathrm{NaOH}$ 0,1 mol L-1 e agitação em alta rotação, durante $15 \mathrm{~min}$. As frações areia grossa e fina foram separadas por tamização, a argila foi determinada pelo método da pipeta, e a fração silte calculada por diferença (Embrapa, 1997).

Para a determinação do equivalente de umidade, amostras de solo em caixas com uma fina tela de arame numa das extremidades e papel de filtro sobre a tela foram saturadas por um período mínimo de $6 \mathrm{~h}$ e colocadas para centrifugar a $2.440 \mathrm{rpm}$, por $30 \mathrm{~min}$. Cada amostra foi, então, transferida para um recipiente com tampa, previamente tarado, com aproximação de $0,01 \mathrm{~g}(\mathrm{Mr}=$ massa do recipiente $) . \mathrm{O}$ conjunto ( $\mathrm{Mr}+$ solo + água), depois de pesado, foi levado à estufa a $100-105^{\circ} \mathrm{C}$, durante $48 \mathrm{~h}$, sendo depois transferido para o dessecador até atingir a temperatura ambiente para ser novamente pesado.

\section{Análises químicas}

As análises químicas foram realizadas em laboratórios do Departamento de Solos da Universidade Federal de Viçosa. $\mathrm{O}$ pH foi determinado potenciometricamente na suspensão solo-água 1:2,5. Cálcio e magnésio trocáveis foram extraídos com $\mathrm{KCl}$
$1 \mathrm{~mol} \mathrm{~L}-1$, pH 7,0, e dosados por espectrofotometria de absorção atômica (Defelipo \& Ribeiro, 1997). K, Na, Fe, Zn, Mn e Cu trocáveis foram extraídos em solução de $\mathrm{HCl}$ 0,05 mol L-1 e $\mathrm{H}_{2} \mathrm{SO}_{4} 0.025 \mathrm{~mol} \mathrm{~L}^{-1}$ (Mehlich-1), sendo o K dosado por espectrofotometria de emissão de chama (Defelipo \& Ribeiro, 1997), enquanto os demais por espectrofotometria de absorção atômica (Embrapa, 1999b). O Al trocável foi extraído com KCl $1 \mathrm{~mol} \mathrm{~L}^{-1}$ e determinado por titulação com $\mathrm{NaOH}$ $0,025 \mathrm{~mol} \mathrm{~L}^{-1}$. A acidez extraível $(\mathrm{H}+\mathrm{Al})$ foi extraída com acetato de cálcio $0,5 \mathrm{~mol} \mathrm{~L}^{-1}$ tamponada em $\mathrm{pH}$ 7,0 e determinada por titulação com $\mathrm{NaOH} 0,06 \mathrm{~mol} \mathrm{~L}^{-1}$. O $\mathrm{P}$ assimilável foi extraído com Mehlich-1 e determinado por fotocolorimetria. O CO foi determinado pelo método de Walkley-Black, e a matéria orgânica (MO) do solo estimada pela equação: $\mathrm{MO}=$ $\mathrm{CO} \times 1,724$. O N foi extraído pelo método de Kjeldahl através de destilação a vapor e determinado por acidimetria. Metais pesados selecionados $(\mathrm{Pb}, \mathrm{Ni}, \mathrm{Cr}$ e Cd) foram extraídos pelo extrator $\mathrm{HCl} 0,05 \mathrm{~mol} \mathrm{~L}^{-1}$ $\mathrm{e}_{2} \mathrm{SO}_{4}$ 0,025 mol L-1 (Mehlich-1) e determinados por espectrofotometria de absorção atômica (Embrapa, 1999b). O P remanescente (Prem) foi determinado com o P em solução após agitação por 01 hora de $60 \mathrm{mg} \mathrm{L}^{-1}$ de $\mathrm{P}$ em $\mathrm{CaCl}_{2} 0,01 \mathrm{~mol} \mathrm{~L}^{-1}$, na relação solo:solução 1:10 (Alvarez V. et al., 1999).

\section{RESULTADOS E DISCUSSÃO}

\section{Relação solo-paisagem na ilha da Trindade}

Os perfis de solos amostrados e as características dos distintos pedoambientes ao longo da topossequência são mostrados na figura 1 e quadro 1 , respectivamente. Esses solos são bastante representativos de sistemas pedogenéticos desenvolvidos de rochas vulcânicas em regime oceânico, isolamento geográfico e ausência de mesofauna nativa. Dos dez perfis caracterizados na Ilha da Trindade, quatro foram enquadrados na ordem dos Neossolos, cinco na dos Cambissolos e um na dos Organossolos (Embrapa, 2006). Os Neossolos estão tipicamente localizados nos sopés das encostas, ao passo que os Cambissolos e o Organossolo encontramse associados aos relevos mais altos da Ilha, ou, ainda, no caso dos Cambissolos, associados aos relevos residuais (necks) fonolíticos.

Conforme observado, as condições do relevo e, principalmente, as características dos solos guardam estreita relação com a cobertura vegetal. A presença e o estágio de desenvolvimento da vegetação foram identificados como fatores de fundamental importância na pedogênese e conservação dos solos, sobretudo em relação à manutenção da sua estabilidade diante dos processos erosivos. Além disso, observou-se atividade ornitogênica atual ou pretérita em muitas partes da ilha, especialmente nas partes mais íngremes, com ninhais de várias espécies, o que parece resultar em valores anômalos de $\mathrm{P}$. 


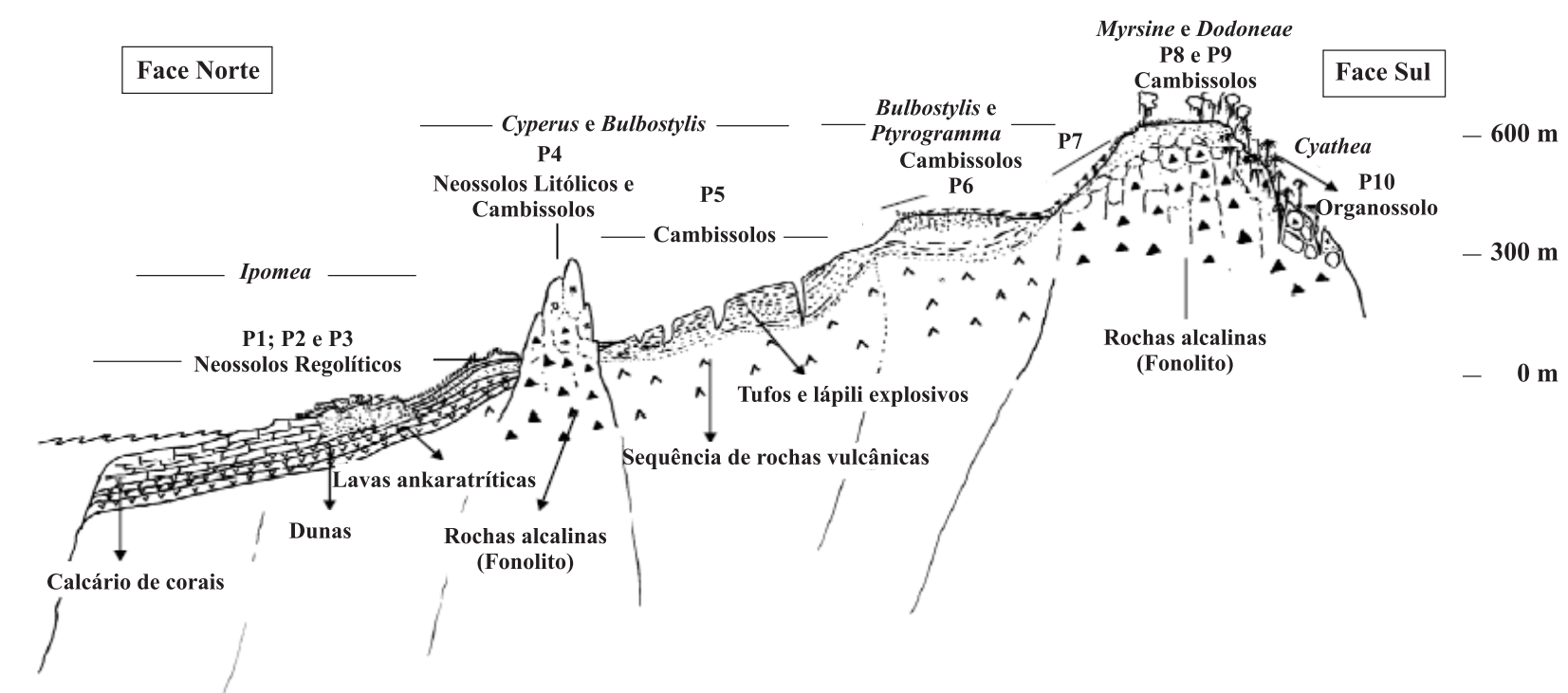

Figura 1. Topossequência representativa dos perfis de solos estudados na ilha da Trindade, com corte geológico esquemático.

O relevo atual da ilha, bem diferente do maciço vulcânico original, evidencia a forte atuação dos agentes intempéricos, associados a processos erosivos, acentuados com a retirada da cobertura vegetal. Conforme o esquema de estágios de formação das ilhas oceânicas de origem vulcânica, apresentado por Wagner et al. (1991), Trindade pode ser enquadrada no quinto estágio, reconhecido como estágio erosional. De acordo com Alves (1998), nesta fase os vulcanismos construtivos já cessaram e há forte erosão da topografia vulcânica, formando vales profundos e platôs sedimentares.

Em todos os solos em que foi identificado maior grau de erosão, observou-se que a vegetação era esparsa e de pequeno porte. Nos perfis P1, P2, P3, P4 e P5 (Quadro 1), localizados em menores altitudes, predominou a espécie endêmica Cyperus atlanticus, caracterizada por ser rasteira, formando touceiras, sem proporcionar ao solo uma cobertura contínua efetiva. Nos perfis P8, P9 e P10, por sua vez, situados em maiores altitudes, a vegetação adquiriu maior densidade e biomassa, destacando-se, por exemplo, a Floresta Nebular de Myrsine floribunda, com cobertura herbácea mista de Pytyrogramma, Cyperus, Bulbostylis e indivíduos jovens de Cyathea, onde a erosão não é aparente. Tais observações evidenciam a importância que o tipo de vegetação e o regime pedobioclimático exercem no controle da perda do solo em Trindade. O perfil P6, localizado na cota de $448 \mathrm{~m}$, num platô situado abaixo do maior pico da Ilha (Pico Desejado com $620 \mathrm{~m}$ ), é um exemplo de uma geoforma aplainada severamente erodida em decorrência da retirada da cobertura vegetal nativa. Nela podem ser encontrados blocos e matacões rochosos de fonolito nas suas bordas, devido à exposição pela erosão laminar severa ocasionada pelo intenso pastoreio de cabras, hoje extintas. Alves (1998) relata que boa parte de Trindade foi outrora ocupada por uma exuberante floresta, dominada pela espécie Colubrina glandulosa, ulteriormente devastada por animais exóticos que se alimentavam das cascas destas árvores e compactavam o solo por meio do pisoteio, proporcionando condições altamente favoráveis à aceleração do escoamento superficial e, por consequência, da perda de solo.

\section{Atributos morfológicos e físicos dos solos da topossequência}

Os atributos físicos dos solos da topossequência em análise na ilha de Trindade refletem a influência marcante do material de origem e da posição topográfica (altimetria). A classificação dos solos e os resultados das análises físicas são mostrados no quadro 2.

Os Neossolos apresentam cores brunadas, muito semelhantes em todos os perfis, mas com textura variando de francoargilosa a areiafranca, dependendo da posição topográfica em que se encontram. São solos que ocupam preferencialmente as partes baixas das encostas, com climas mais sazonais e condições pedoclimáticas acentuadamente secas. A vegetação predominante é de Cyperus atlanticus em todos os perfis de Neossolos (Quadro 1). Dos quatro perfis típicos, apenas o Neossolo Regolítico (P1) não possui rochosidade elevada, como blocos e matacões, já que é formado pelo intemperismo de dunas arenosas carbonáticas misturadas com sedimentos de rochas vulcânicas. Este solo é muito semelhante ao perfil de Neossolo Regolítico bioclástico-carbonático (classificação proposta) descrito por Marques (2004, 2007a,b) e Schaefer et al. (2005) em Fernando de Noronha, mas possui maior contribuição aparente de minerais máficos na fração areia, provavelmente por aportes vulcânicos mais recentes em Trindade. Os perfis que evidenciaram mais problemas de erosão são 
Quadro 1. Localização dos solos estudados e características de seus respectivos pedoambientes na topossequência

\begin{tabular}{|c|c|c|c|c|c|}
\hline Perfil & Localização/ambiente & titude (m) & Rochosidade & Formação geológica & Erosão \\
\hline $\begin{array}{l}\text { P1 - Neossolo } \\
\text { Regolítico } \\
\text { eutrófico } \\
\text { bioclástico- } \\
\text { carbonático } \\
\text { (Proposta de cla }\end{array}$ & $\begin{array}{l}2050520 \text { S; } 2931326 \text { W. Terço superior de Duna } \\
\text { vegetada com Cyperus atlanticus, logo abaixo } \\
\text { da crista fonolítica e tálus, em relevo ondulado. } \\
\text { ssificação) }\end{array}$ & 26 & Não rochoso. & $\begin{array}{l}\text { Dunas quaternárias } \\
\text { de calcários recifais, } \\
\text { com contribuição de } \\
\text { sedimentos de rochas } \\
\text { vulcânicas, subordinada }\end{array}$ & Não aparente. \\
\hline $\begin{array}{l}\text { P2 - Neossolo } \\
\text { Regolítico } \\
\text { Húmico } \\
\text { típico }\end{array}$ & $\begin{array}{l}2050813 \mathrm{~S} ; 2931547 \mathrm{~W} \text {. Área de relevo suave } \\
\text { ondulado, em terço inferior de rampa } \\
\text { pedimentada, com blocos e matacões rochosos. } \\
\text { Representa o nível mais baixo de rampas } \\
\text { pedimentadas atrás do POIT e da Praia dos } \\
\text { Portugueses, recoberta de Cyperus atlanticus } \\
\text { e, revegetação de Colubrina glandulosa com } \\
\text { quatro anos, esparsa. }\end{array}$ & 49 & $\begin{array}{l}\text { Rochoso com mais de } \\
25 \% \text { da área coberta } \\
\text { de blocos/matacões } \\
\text { de fragmentos de } \\
\text { lava ankaratritica } \\
\text { e fonolitos. }\end{array}$ & $\begin{array}{l}\text { Depósitos de tálus } \\
\text { rochoso de blocos da } \\
\text { Formação Trindade } \\
\text { e Desejado, com } \\
\text { sedimentos } \\
\text { inconsolidados de } \\
\text { pedimentação. }\end{array}$ & $\begin{array}{l}\text { Em sulcos e } \\
\text { ravinas, forte. }\end{array}$ \\
\hline $\begin{array}{l}\text { P3 - Neossolo } \\
\text { Regolítico } \\
\text { eutrófico } \\
\text { típico }\end{array}$ & $\begin{array}{l}2051621 \text { S; } 2930960 \text { W. Topo aplainado do } \\
\text { platô do Príncipe, abaixo da saia de tálus do } \\
\text { Morro da Gruta, com vegetação de Cyperus } \\
\text { atlanticus, em relevo plano, com poucos blocos } \\
\text { e matacões rochosos de lava ankaratrítica. }\end{array}$ & 91 & $\begin{array}{l}\text { Rochoso com } 5-10 \% \\
\text { da área coberta de } \\
\text { blocos/matacões de } \\
\text { fragmentos de lava. }\end{array}$ & $\begin{array}{l}\text { Escórias globosas } \\
\text { e fibrosas, } \\
\text { horizontalmente } \\
\text { dispostas no Platô; }\end{array}$ & $\begin{array}{l}\text { Laminar forte, } \\
\text { abaixo do } \\
\text { platô, em } \\
\text { sulcos, severa. }\end{array}$ \\
\hline $\begin{array}{l}\text { P4 - Neossolo } \\
\text { Regolítico } \\
\text { eutrófico } \\
\text { léptico }\end{array}$ & $\begin{array}{l}2051016 \mathrm{~S} ; 2931368 \mathrm{~W} \text {. Terço superior de } \\
\text { rampa logo abaixo da saia de tálus, com } \\
\text { vegetação de Cyperus atlanticus, em relevo } \\
\text { ondulado, com blocos e matacões rochosos de } \\
\text { fonólito do Pico da Bandeira (situado acima). }\end{array}$ & 136 & $\begin{array}{l}\text { Rochoso com mais de } \\
20 \% \text { da área coberta } \\
\text { de blocos/matacões } \\
\text { de fragmentos de } \\
\text { fonolitos. }\end{array}$ & $\begin{array}{l}\text { Leque coluvial } \\
\text { pedimentado da saia } \\
\text { do Pico da Bandeira, } \\
\text { com tipos fonolíticos. }\end{array}$ & $\begin{array}{l}\text { Laminar forte } \\
\text { e em sulcos, } \\
\text { severa. }\end{array}$ \\
\hline $\begin{array}{l}\text { P5 - Cambissolo } \\
\text { Háplico Ta } \\
\text { eutrófico } \\
\text { típico }\end{array}$ & $\begin{array}{l}2051359 \mathrm{~S} ; 2931500 \mathrm{~W} \text {. Terço inferior da borda } \\
\text { do Morro Vermelho, na saia abaixo do Pico do } \\
\text { Elefante com Cyperus atlanticus. }\end{array}$ & 196 & $\begin{array}{l}\text { Tufos e colúvios da } \\
\text { Formação do Morro } \\
\text { Vermelho (lavas } \\
\text { ankaratríticas). }\end{array}$ & $\begin{array}{l}\text { Tufos e colúvios da } \\
\text { Formação do Morro } \\
\text { Vermelho (lavas } \\
\text { ankaratríticas). }\end{array}$ & $\begin{array}{l}\text { Em sulcos, } \\
\text { severa, } \\
\text { laminar forte } \\
\text { com voçorocas } \\
\text { de canais de } \\
\text { escoamento } \\
\text { concentrado. }\end{array}$ \\
\hline $\begin{array}{l}\text { P6 - Cambissolo } \\
\text { Ta eutrófico } \\
\text { típico }\end{array}$ & $\begin{array}{l}2051545 \mathrm{~S} ; 2932385 \mathrm{~W} \text {. Topo aplainado do } \\
\text { platô abaixo do Pico do Desejado, vegetação de } \\
\text { Bulbostylis nesiotis e alguns Cyperus, em } \\
\text { relevo plano, com blocos e matacões rochosos } \\
\text { de fonolito nas vizinhanças da borda do platô } \\
\text { devido à erosão laminar severa pelo pastoreio } \\
\text { de cabras. }\end{array}$ & 448 & $\begin{array}{l}\text { Rochoso em menos } \\
\text { de } 5 \% \text { da área, } \\
\text { blocos/matacões } \\
\text { de fragmentos } \\
\text { de fonolitos. }\end{array}$ & $\begin{array}{l}\text { Tufos básicos em } \\
\text { platô latossolizado } \\
\text { in situ, com } \\
\text { contribuições } \\
\text { coluviais; material } \\
\text { mais antigo e } \\
\text { conservado da ilha, } \\
\text { pela natureza porosa } \\
\text { dos tufos. }\end{array}$ & $\begin{array}{l}\text { Laminar forte } \\
\text { e em sulcos, } \\
\text { severa nas } \\
\text { bordas. }\end{array}$ \\
\hline $\begin{array}{l}\text { P7 - Cambissolo } \\
\text { Háplico Ta } \\
\text { distrófico } \\
\text { típico }\end{array}$ & $\begin{array}{l}2051356 \mathrm{~S} ; 2932317 \mathrm{~W} \text {. Base de rampa na saia } \\
\text { do pico do Desejado, na área coberta de } \\
\text { Pytirogramma calomelanos onde foram feitas } \\
\text { covas para Colubrina glandulosa; em relevo } \\
\text { local suave, geralmente montanhoso, com raros } \\
\text { blocos e matacões rochosos de fonolito recoberto } \\
\text { de líquens crustosos e foliosos. Representa o nível } \\
\text { elevado típico de cobertura de Pytyrogramma. } \\
\text { Calomelanos abaixo do Desejado. }\end{array}$ & 478 & $\begin{array}{l}\text { Rochoso com } 15-20 \% \\
\text { da área coberta } \\
\text { de blocos/matacões } \\
\text { de fonolitos. }\end{array}$ & $\begin{array}{l}\text { Depósito de tálus } \\
\text { de pedimentos da } \\
\text { Formação Desejado, } \\
\text { com tipos fonolíticos. }\end{array}$ & $\begin{array}{l}\text { Laminar } \\
\text { moderada, na } \\
\text { encosta abaixo } \\
\text { em sulcos e } \\
\text { ravinas, forte. }\end{array}$ \\
\hline $\begin{array}{c}\text { P8 - Cambissolo } \\
\text { Háplico } \\
\text { alítico } \\
\text { típico }\end{array}$ & $\begin{array}{l}2050978 \mathrm{~S} ; 2932781 \mathrm{~W} \text {. Terço superior de } \\
\text { vertente de face sul, mais úmida, ravinada, } \\
\text { com floresta nebular de Cyathea delgadii com } \\
\text { comunidade de sub-bosque de Peperomia } \\
\text { glabella, em relevo montanhoso, com poucos } \\
\text { blocos e matacões rochosos de fonolito } \\
\text { recoberto de líquens crustosos e foliosos. } \\
\text { Representa o nível mais elevado e antigo de } \\
\text { floresta de pteridófitas da Ilha, abaixo do Platô } \\
\text { do Desejado (trilha Desejado-Fazendinha). }\end{array}$ & 517 & $\begin{array}{l}\text { Não rochoso, com } \\
\text { alguns afloramentos } \\
\text { em } 20 \% \text { da área } \\
\text { (fragmentos de } \\
\text { fonolitos). }\end{array}$ & $\begin{array}{l}\text { Formação Desejado, } \\
\text { com tipos fonolíticos. }\end{array}$ & $\begin{array}{l}\text { Local não } \\
\text { aparente, na } \\
\text { encosta abaixo } \\
\text { em sulcos e } \\
\text { ravinas, forte. }\end{array}$ \\
\hline $\begin{array}{l}\text { P9 - Cambissolo } \\
\text { Háplico Ta } \\
\text { distrófico } \\
\text { típico }\end{array}$ & $\begin{array}{l}2051162 \mathrm{~S} ; 2932533 \mathrm{~W} \text {. Topo do platô do } \\
\text { desejado voltado à face sul, mais úmida, com } \\
\text { vegetação de Floresta de Myrsine floribunda, } \\
\text { em relevo local plano a suave ondulado, com } \\
\text { raros blocos e matacões rochosos de fonolito } \\
\text { aflorantes. }\end{array}$ & 599 & $\begin{array}{l}\text { Não rochoso, com } \\
\text { menos de } 5 \% \text { da } \\
\text { área coberta de } \\
\text { fragmento de } \\
\text { fonolitos. }\end{array}$ & $\begin{array}{l}\text { Fonolito da formação } \\
\text { Desejado. }\end{array}$ & Não aparente. \\
\hline $\begin{array}{l}\text { P10 - Organossolo } \\
\text { Fólico } \\
\text { fíbrico } \\
\text { típico }\end{array}$ & $\begin{array}{l}2051241 \mathrm{~S} ; 2932550 \mathrm{~W} \text {. Topo de anfiteatro } \\
\text { ravinado com vegetação de Cyathea delgadii, } \\
\text { em relevo montanhoso, em terço superior de } \\
\text { vertente, com blocos e matacões rochosos de } \\
\text { fonolito recoberto de líquens crustosos e } \\
\text { foliosos. Representa o nível elevado da Ilha, } \\
\text { abaixo do Platô do Desejado, com Myrsine }\end{array}$ & 554 & $\begin{array}{l}\text { Rochoso com mais de } \\
25 \% \text { da área coberta } \\
\text { de blocos/matacões } \\
\text { de fonolitos. }\end{array}$ & $\begin{array}{l}\text { Formação Desejado, } \\
\text { com tipos fonolíticos. }\end{array}$ & $\begin{array}{l}\text { Local não } \\
\text { aparente, na } \\
\text { encosta abaixo } \\
\text { em sulcos e } \\
\text { ravinas, forte. }\end{array}$ \\
\hline
\end{tabular}


Quadro 2. Atributos morfológicos e físicos dos solos da topossequência na ilha da Trindade

\begin{tabular}{|c|c|c|c|c|c|c|c|c|c|}
\hline \multirow{3}{*}{ Hor. } & \multirow{3}{*}{ Prof. } & \multicolumn{4}{|c|}{$<2 \mathrm{~mm}$} & \multirow{3}{*}{ E. umid. } & \multirow{3}{*}{$\begin{array}{l}\text { Classe } \\
\text { textural }\end{array}$} & \multirow{3}{*}{ Estrutura/transição } & \multirow{3}{*}{$\begin{array}{l}\text { Cor úmida } \\
\text { (Munsell) }\end{array}$} \\
\hline & & \multicolumn{2}{|c|}{ Areia } & \multirow[b]{2}{*}{ Silte } & \multirow[b]{2}{*}{ Argila } & & & & \\
\hline & & Grossa & Fina & & & & & & \\
\hline & $\mathrm{cm}$ & 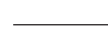 & - de & $\mathrm{kg}^{-1}$ & - & $\mathrm{kg} \mathrm{kg}^{-1}$ & & & \\
\hline \multicolumn{10}{|c|}{ Perfil 1 - Neossolo Regolítico eutrófico bioclástico-carbonático (Proposta de classificação) } \\
\hline A & $0-20$ & 75 & 11 & 5 & 9 & 0,146 & Areia-Franca & $\begin{array}{l}\text { Grão simples/gradual, } \\
\text { plana }\end{array}$ & $\begin{array}{l}\text { Bruno-amarelado- } \\
\text { escuro }\end{array}$ \\
\hline $\mathrm{C}_{1}+\mathrm{C}_{2}$ & $20-80$ & 79 & 6 & 6 & 9 & 0,131 & Areia-Franca & Grão simples & Bruno-amarelado \\
\hline \multicolumn{10}{|c|}{ Perfil 2 - Neossolo Regolítico Húmico típico } \\
\hline $\mathrm{A}_{1}$ & $0-10$ & 17 & 8 & 44 & 31 & 0,478 & $\begin{array}{l}\text { Franco- } \\
\text { Argilosa }\end{array}$ & $\begin{array}{l}\text { Mod. Peq. } \\
\text { Granular/gradual, plana }\end{array}$ & $\begin{array}{l}\text { Bruno-acinzentado } \\
\text { muito escuro }\end{array}$ \\
\hline $\mathrm{A}_{2}$ & $10-25$ & 14 & 9 & 46 & 31 & 0,490 & $\begin{array}{l}\text { Franco- } \\
\text { Argilosa }\end{array}$ & $\begin{array}{l}\text { Mod. Peq a med. Bl. sub. } \\
\text { e mod. Peq. Granular/ } \\
\text { clara, plana }\end{array}$ & $\begin{array}{l}\text { Bruno-avermelhado- } \\
\text { escuro }\end{array}$ \\
\hline $\mathrm{C}_{1}$ & $25-40$ & 58 & 9 & 17 & 16 & 0,392 & $\begin{array}{l}\text { Franco- } \\
\text { Arenosa }\end{array}$ & $\begin{array}{l}\text { Grão simples/ } \\
\text { gradual, plana }\end{array}$ & Bruno \\
\hline $\mathrm{C}_{2}$ & $40-55$ & 63 & 7 & 14 & 16 & 0,330 & $\begin{array}{l}\text { Franco- } \\
\text { Arenosa }\end{array}$ & Grão simples & Bruno escuro \\
\hline \multicolumn{10}{|c|}{ Perfil 3 - Neossolo Regolítico eutrófico típico } \\
\hline $\mathrm{A}_{1}$ & $0-10$ & 31 & 12 & 39 & 18 & 0,349 & Franco & Fraca méd. Granular & Bruno muito escuro \\
\hline $\mathrm{A}_{2}$ & $10-30$ & 53 & 17 & 22 & 8 & 0,292 & $\begin{array}{l}\text { Franco- } \\
\text { Arenosa }\end{array}$ & $\begin{array}{l}\text { Grão simples/clara, } \\
\text { plana }\end{array}$ & $\begin{array}{l}\text { Bruno-acinzentado } \\
\text { muito escuro }\end{array}$ \\
\hline $\mathrm{C}_{1}$ & $30-50$ & 77 & 4 & 11 & 8 & 0,156 & Areia-Franca & $\begin{array}{l}\text { Grão simples/clara, } \\
\text { ondulada }\end{array}$ & $\begin{array}{l}\text { Cinzento- } \\
\text { avermelhado-escuro }\end{array}$ \\
\hline $\mathrm{C}_{2}$ & $50-60$ & 30 & 14 & 36 & 20 & 0,330 & Franco & $\begin{array}{l}\text { Fraca méd. Bl. Sub/ } \\
\text { gradual, plana }\end{array}$ & $\begin{array}{l}\text { Bruno-amarelado- } \\
\text { escuro }\end{array}$ \\
\hline $\mathrm{C}_{3}$ & $60-70$ & 78 & 6 & 10 & 6 & 0,153 & Areia-Franca & Grão simples & Preto-avermelhado \\
\hline \multicolumn{10}{|c|}{ Perfil 4 - Neossolo Regolítico eutrófico léptico } \\
\hline $\mathrm{A}_{1}$ & $0-10$ & 28 & 7 & 43 & 22 & 0,208 & Franco & $\begin{array}{l}\text { Moderada } \\
\text { peq.med.granular }\end{array}$ & $\begin{array}{l}\text { Bruno-acinzentado } \\
\text { muito escuro }\end{array}$ \\
\hline $\mathrm{A}_{2}$ & $10-25 / 50$ & 24 & 8 & 45 & 23 & 0,255 & Franco & $\begin{array}{l}\text { Fraca e Moderada } \\
\text { peq.med.granular }\end{array}$ & $\begin{array}{l}\text { Bruno-acinzentado- } \\
\text { escuro }\end{array}$ \\
\hline $\mathrm{C}$ & $50-60$ & 29 & 6 & 34 & 31 & 0,357 & $\begin{array}{l}\text { Franco- } \\
\text { Argilosa }\end{array}$ & massivo (saprolito) & $\begin{array}{l}\text { Bruno-amarelo- } \\
\text { escuro }\end{array}$ \\
\hline $\mathrm{CR}$ & $60-80$ & 27 & 8 & 36 & 29 & 0,373 & $\begin{array}{l}\text { Franco- } \\
\text { Argilosa }\end{array}$ & $\begin{array}{l}\text { Blocos arredondados, } \\
\text { fragmentário, com } \\
\text { bolsões }\end{array}$ & Bruno \\
\hline \multicolumn{10}{|c|}{ Perfil 5 - Cambissolo Háplico Ta eutrófico típico } \\
\hline $\mathrm{A}_{1}$ & $0-10$ & 6 & 4 & 42 & 48 & 0,336 & Argila-Siltosa & $\begin{array}{l}\text { Moderada } \\
\text { peq.med.granular/ } \\
\text { gradual, plana }\end{array}$ & $\begin{array}{l}\text { Vermelho escuro- } \\
\text { acinzentado }\end{array}$ \\
\hline $\mathrm{AB}$ & $10-20$ & 5 & 4 & 37 & 54 & 0,337 & Argila & $\begin{array}{l}\text { Mod. Med. Bl.sub. e } \\
\text { moderada } \\
\text { peq.med.granular/ } \\
\text { gradual plana }\end{array}$ & $\begin{array}{l}\text { Bruno-avermelhado- } \\
\text { escuro }\end{array}$ \\
\hline $\mathrm{Bt}$ & $20-50$ & 4 & 4 & 32 & 60 & 0,368 & Argila & $\begin{array}{l}\text { Forte med. e gr. Bl. Sub. } \\
\text { Cerosidade forte } \\
\text { comum/gradual, plana }\end{array}$ & $\begin{array}{l}\text { Bruno-avermelhado- } \\
\text { escuro }\end{array}$ \\
\hline $\mathrm{BC}$ & $50-70$ & 4 & 4 & 32 & 60 & 0,390 & Argila & $\begin{array}{l}\text { Mod.méd. bl. Sub Cerosid. } \\
\text { Mod. Abund. e Maciça mod. } \\
\text { Coesa/ gradual, ondulada }\end{array}$ & $\begin{array}{l}\text { Bruno-avermelhado- } \\
\text { escuro }\end{array}$ \\
\hline $\mathrm{C}_{1}$ & $70-100$ & 3 & 2 & 34 & 61 & 0,387 & Muito Argilosa & $\begin{array}{l}\text { Maciça mod. Coesa/ } \\
\text { gradual, ondulada }\end{array}$ & $\begin{array}{l}\text { Bruno-avermelhado } \\
\text { escuro }\end{array}$ \\
\hline $\mathrm{C}_{2}$ & $100-140$ & 1 & 2 & 40 & 57 & 0,396 & Argilsa-Siltosa & Maciça mod. Coesa & $\begin{array}{l}\text { Bruno-avermelhado- } \\
\text { escuro }\end{array}$ \\
\hline $\mathrm{A}$ & $0-5$ & 7 & 6 & 39 & $\begin{array}{l}\text { Perfil } 6- \\
\quad 48\end{array}$ & $\begin{array}{l}\text { ambissolo } \\
0,377\end{array}$ & $\begin{array}{l}\text { Háplico Ta eutróf } \\
\text { Argila }\end{array}$ & $\begin{array}{l}\text { Mo típico } \\
\text { Moderada } \\
\text { peq.med.granular/ } \\
\text { gradual, plana }\end{array}$ & Bruno-escuro \\
\hline $\mathrm{Bi}_{1}$ & $5-50$ & 5 & 6 & 38 & 51 & 0,434 & Argila & $\begin{array}{l}\text { Mod. Peq e méd. Bl. } \\
\text { Sub./gradual, ondulada }\end{array}$ & Bruno-escuro \\
\hline $\mathrm{Bi}_{2}$ & $50-120$ & 6 & 7 & 41 & 46 & 0,515 & Argila-Siltosa & Mod. méd. Bl. Sub. & Bruno-escuro \\
\hline
\end{tabular}

Continua... 
Quadro 2. Continuação

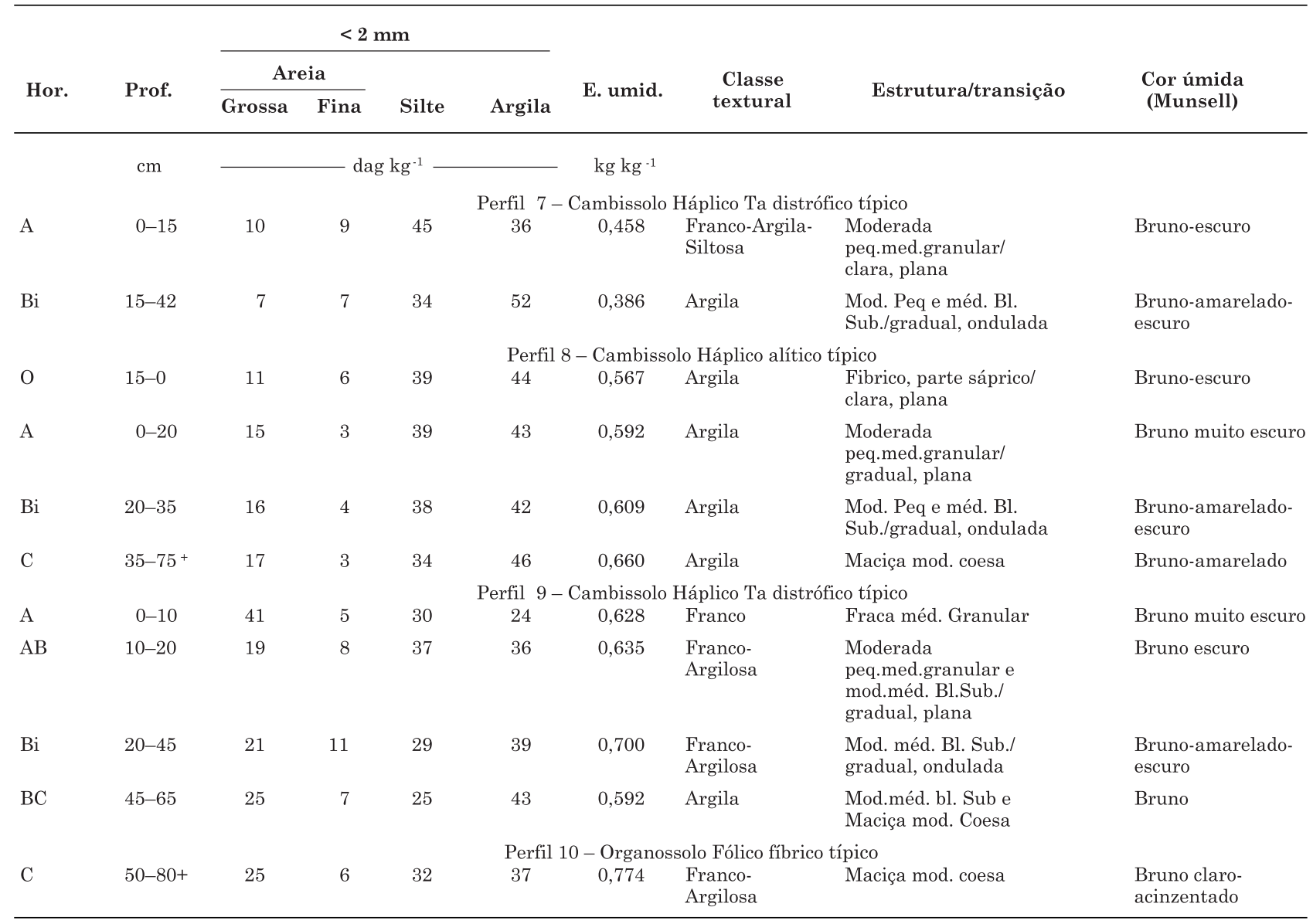

os que possuem maior porcentagem de silte em sua textura (Quadro 2), o que corrobora aos observações de Resende (1985) sobre a maior erodibilidade de solos ricos em silte e dos solos de ilhas oceânicas em geral, onde o desenvolvimento da estrutura é sempre menor, com exceção do Perfil 5 encontrado pelo mesmo autor, com desenvolvimento estrutural de moderado a forte.

Segundo Ribeiro et al. (2003) e Marques (2004, 2007a), os Neossolos Regolíticos encontrados em Fernando de Noronha apresentam sequência de horizontes $\mathrm{A} / \mathrm{C}$, com textura arenosa, estrutura em grãos simples e outras características morfológicas típicas de Neossolos Quartzarênicos, dos quais se diferenciam pela ausência do quartzo nas frações areia e cascalho. Estas frações são constituídas, como em Trindade, por minerais primários e, principalmente, grãos de calcários de origem biogênica, subarredondados e pouco trabalhados, provenientes de fragmentos de conchas de moluscos, crustáceos, corais, foraminíferos e algas carbonáticas. Esses resultados revelam forte semelhança com o perfil P1 estudado na Ilha de Trindade, que se diferencia daquele apenas pela maior contribuição de grãos minerais de origem vulcânica nas frações areia e cascalho, à semelhança de solos correlatos a Neossolos Regolíticos da Ilha do Fogo, em Cabo Verde (Faria, 1974). As dunas de Fernando de Noronha foram desenvolvidas de sedimentos mais extensos, antigos e erodidos, bem como sobre uma plataforma carbonática de bioclásticos (corais e algas) bem mais ampla e antiga que Trindade. As dunas em Trindade encontram-se inativas na atualidade e sua formação deve corresponder a períodos mais secos do Quaternário, como em Noronha.

O Neossolo Regolítico (P4) é um solo pouco evoluído, com o perfil constituído de horizontes A sobre $\mathrm{C}$ e textura de franco a francoargilosa. Em subsuperfície é constituído por pedras e fragmentos de rochas pouco alterados, entremeados de material fino mais intemperizado, sem constituir um contato lítico típico. Parte é desenvolvida de escórias vulcânicas e tufos provindos predominantemente de ankaratritos. Por essas características, é extremamente semelhante aos Neossolos Litólicos das partes mais elevadas de Fernando de Noronha estudados por Ribeiro et al. (2003) e Marques (2004, 2007a). Neles, a camada R é, geralmente, constituída por matacões arredondados de rocha basáltica, perfazendo mais de $90 \%$ do volume de sua massa, sendo o restante preenchido por material 
intemperizado $(\mathrm{Cr})$ ou proveniente de penetrações dos horizontes superficiais. Outros solos com semelhante contato lítico "fragmentário" foram descritos em diversas ilhas oceânicas (Ricardo et al., 1977; Fauzi \& Stoops, 2004; Gerard et al., 2007). Neossolos com este tipo de substrato (CR) fragmentado têm um comportamento bastante diferente dos Neossolos que transicionam para um substrato de rocha consolidada e contínua, pois permitem a penetração das raízes e a infiltração da água, proporcionando condições mais favoráveis ao desenvolvimento da vegetação. A disponibilidade de água no solo não corresponderia, assim, ao que seria suposto para um contato lítico típico. Este atributo foi incorporado pelo Sistema Brasileiro de Classificação de Solos (Embrapa, 2006) na condição de contato lítico fragmentário. A ocorrência de Neossolos eutróficos (P4) com sequência de horizontes A-C-CR, com contato lítico a pouco mais de $50 \mathrm{~cm}$ (no caso, $60 \mathrm{~cm}$ ), corrobora a necessidade da criação de uma nova subordem, a dos Neossolos "Saprolíticos", como proposto por Marques et al. (2007a) para solo semelhante em Noronha.

A classe dos Cambissolos, em sua maioria, também apresenta cores brunadas, textura média a argilosa, com teores de argila entre 24 e $52 \%$. São derivados, principalmente, de rochas alcalinas, sendo solos medianamente profundos, com rochosidade variável, tendo o perfil P7 de 15 a $20 \%$ de área coberta com matacões. Estão relacionados com posições geomórficas de terço médio a superior das encostas, em áreas declivosas, associadas à vegetação mista mais contínua da ilha, com a predominância de pteridófitas, ciperáceas e floresta nebular de comunidades monodominantes de Myrsine floribunda (P8) ou de samambaia gigante (Cyathea delgadii) (P9).

Os perfis P9 e P7 foram classificados como Cambissolos Háplicos Ta distróficos típicos, diferenciando-se do P8, um Cambissolo Háplico Alítico, pela menor profundidade dos perfis e porque este apresenta um horizonte $\mathrm{O}$ seguido pelo horizonte $\mathrm{A}$, com ocorrência do horizonte Bi delgado. É formado por materiais hísticos ou até turfosos, responsáveis pela formação do horizonte $\mathrm{O}$, atípico para um relevo tão acidentado e bem drenado. Possui cores mais escuras na superfície devido à grande quantidade de matéria orgânica, que influi na alta retenção de água, o que ocorre em menor proporção também nos outros dois perfis. Não revelam qualquer semelhança com Cambissolos de Fernando de Noronha, pois ocorre em posições altimétricas e climáticas que não ocorrem naquela ilha. Constituem solos exclusivamente endêmicos à Trindade, expressos pelas condições particulares ocorrentes na ilha para a formação deste horizonte hístico, ou seja, acumulação de MO em razão da pouca atividade de organismos do solo capazes de promover sua decomposição, e pela umidade constante das encostas voltadas à face sul da ilha.

Segundo Marques (2004, 2007b), o Cambissolo Háplico Tb distrófico típico de Fernando de Noronha está relacionado com as posições mais altas da Ilha, ocorrendo no terço inferior das encostas dos morros fonolíticos, em altitudes em torno de 80-100 m e relevo ondulado, sendo os solos mais profundos e intemperizados de Noronha.

Um dos perfis estudados (P6), enquadrado como Cambissolo, apresenta morfologia semelhante à dos Latossolos, possui cores brunadas e se encontra num relevo local mais plano, localizado em platô a $450 \mathrm{~m}$. É bastante profundo e poroso, sendo o horizonte B encontrado até $120 \mathrm{~cm}$. Há presença de muitas locas de caranguejos, mas a atividade biológica aparente atual é reduzida. Mostra-se pouco denso e muito friável na base (50-120 cm), aparentando possuir material alofânico (caráter ândico). Nesse solo, praticamente não há fragmentos de rochas, nem minerais primários em evidência, apenas raros grãos minerais maiores do que $2 \mathrm{~mm}$, de acordo com análises mineralógicas realizadas (Clemente, 2006). Possui típica cobertura vegetal de ciperáceas (Bulbostylis), sendo o solo mais desenvolvido e conservado da ilha em platô com tufos básicos intemperizados in situ. Nesse platô, a erosão laminar é forte, ocorrendo grandes sulcos nas bordas.

Os Cambissolos latossólicos, assim como os Andossolos encontrados em ilhas oceânicas, de modo geral, são desenvolvidos em condições climáticas mais úmidas, que não ocorrem na maioria das ilhas oceânicas atlânticas de origem vulcânica, que apresentam climas mais secos. Podem ser encontrados, contudo, nas áreas de altitude mais elevadas dessas ilhas, onde a umidade orográfica é superior à das partes mais baixas, como é o caso de Trindade, formando microclimas. O material de origem no qual se desenvolvem esses solos, de forma geral, são materiais pomíticos ou tufos muito porosos, fragmentados e com uma enorme superfície específica, além de ricos em $\mathrm{Fe}$ e de fácil intemperismo (Faria, 1974). No Organossolo (P10) sob floresta de pteridófita (Cyathea) só foi possível fazer a análise física no horizonte $\mathrm{C}$, devido ao material do horizonte $\mathrm{O}$ ser muito fibroso com grande predominância de material vegetal inalterado. $\mathrm{O}$ horizonte $\mathrm{O}$ é muito espesso, chegando a $50 \mathrm{~cm}$, em contato com o saprolito pouco alterado de fonolito ou andesito sódico, fraturados e penetrados por materiais fíbricos, preenchendo fraturas e entremeando blocos menos intemperizados. Como a mesofauna do solo é praticamente nula na ilha, não há saprófagos ou pedoturbação visíveis no material fibroso acumulado sobre o saprolito, originando um Organossolo em condições de relevo montanhoso e bem drenado. Os Organossolos sob Cyathea só ocorrem na vertente sul da ilha, por ser mais fria e úmida. A elevada capacidade de retenção de água, medida pelo equivalente de umidade, mostra a influência de material amorfo na retenção de água. Na descrição dos solos da ilha do Fogo, Faria (1974) reporta que o teor de água retido pelos materiais amorfos do tipo alofana é muito considerável, o que é devido à sua elevada microporosidade, pois são materiais dotados de uma elevadíssima superfície específica. 
Em Cabo Verde, segundo Faria (1974), os Organossolos apresentam horizonte $\mathrm{O}$ mais espesso $(0,6$ a $1 \mathrm{~m})$ e teor de matéria orgânica mais elevado que em Trindade. Desenvolvem-se a partir de materiais pomíticos que se apresentam com grau de meteorização mais ou menos avançado. Distribuemse por topografia plana, ligeiramente inclinada e mais raramente passam a acentuados declives.

Situado no terço médio da topossequência, o perfil classificado como Cambissolo Háplico Ta eutrófico típico (P5) apresentou cores avermelhadas escuras e textura mais argilosa, macroestrutura em blocos angulares e subangulares fortemente desenvolvida, apresentando cerosidade moderada, ou seja, uma morfologia de campo típica de Nitossolo, embora não possa ser classificado como tal pelo SiBCS (Embrapa, 2006). Trata-se de um solo profundo e com presença de fragmentos de rochas e matacões, evidenciando pouca atividade biológica além dos abundantes canais de caranguejos e eventuais baratas. Ocorrem em paisagem de solos decapitados, cobertos por espécie de Malvaceae, mas cuja vegetação predominante nos solos mais preservados é de Cyperus atlanticus. São os solos mais erodidos da ilha, com erosão em sulcos severa, laminar forte e voçorocas desenvolvidas ao longo de canais de escoamento concentrados. Faria (1974) descreveu um perfil correlato, na Ilha do Fogo, em Cabo Verde, sendo solo também profundo, mas com cores um pouco mais claras e textura francoargilossiltosa e argilosa. Nunes (1962) descreveu três perfis muito semelhantes na ilha de São Nicolau, apresentando cores mais claras com profundidade e textura bem semelhantes.

A atividade biológica nos solos da ilha é restrita aos microrganismos do solo, sendo a mesofauna praticamente restrita a baratas domésticas introduzidas na ilha e raros anelídeos presentes nas partes elevadas, onde houve ninhais e ocorre manta orgânica. Em virtude do isolamento, não se observam térmitas e outros detritívoros, importantes agentes de formação da estrutura dos solos tropicais (Schaefer, 2001), mas há formigas pequenas nas imediações do Posto Oceanográfico da ilha da Trindade (POIT). Os canais biológicos observados são superficiais, formados quase exclusivamente por túneis abandonados do caranguejo terrestre Gecarcinus sp. Assim, a ausência de Latossolos em Trindade deve ser creditada à fraca ou ausente pedoturbação pelos organismos do solo, que impossibilita a formação de horizonte microgranular espesso e uniforme, apesar do grau de intemperismo mais elevado nas partes altas.

Apesar de a tendência de textura mais argilosa mostrar maior equivalente de umidade, os resultados evidenciaram que esse não é o caso dos solos estudados, o que se deve ao fato do intemperismo do material de origem vulcânica possivelmente produzir muitos minerais amorfos, ou de baixa cristalinidade, que possuem grande capacidade de retenção de água, como reportado por Faria (1974) para outras ilhas vulcânicas atlânticas.
A atividade de avifauna nas proximidades dos perfis P4 e P8 indicam que esses solos podem ter sofrido influência ornitogênica, afetando sua morfologia e atributos químicos, discutidos a seguir.

\section{Atributos químicos dos solos da topossequência}

A classificação dos solos e os resultados das análises químicas são mostrados no quadro 3. Os solos da Ilha de Trindade apresentam uma estreita relação com as características químicas das rochas que compõem a paisagem, em função do pequeno grau de evolução da área e dos processos erosivos que são favorecidos pelo relevo íngreme, da pouca profundidade dos solos e da ausência de uma cobertura vegetal mais densa. Dessa forma, os solos apresentam, de maneira geral, altos teores de nutrientes em relação aos valores de referência para áreas tropicais (Alvarez V. et al., 1999), com destaque para o $P$, cujos teores são médios a altos para os solos mais arenosos, e muito altos para os solos de textura média a argilosa. A ausência de uma relação direta entre os teores de $\mathrm{P}$ e o teor de MO dos solos estudados indica uma origem predominantemente inorgânica deste nutriente.

Apesar da ocorrência de diferentes materiais de origem, variando desde tipos básicos até ácidos (tufos, basaltos, andesitos, fonolitos, entre outros), resultantes de diferentes fases eruptivas ocorridas na ilha, as concentrações de macro e micronutrientes variam principalmente, em função da localização do solo na paisagem, já que há mistura destes materiais no perfil de alteração. A localização na paisagem influencia também o maior grau de desenvolvimento dos solos, que são mais lixiviados nas porções mais estáveis e elevadas da ilha. Apesar da pequena extensão de Trindade, a sucessão de derrames e explosões em diferentes épocas ocasionou uma sobreposição de materiais, gerando certa dificuldade na interpretação dos resultados químicos.

Os solos apresentaram $\mathrm{pH}$ predominantemente neutro e alcalino e, em menor proporção na faixa ligeiramente ácida ou ácida, mantendo-se os valores com pouca alteração ao longo do perfil. Os solos mais ácidos (P8, P9 e P10) estão localizados em áreas de fonolitos com pouca influência de sedimentos de lavas basálticas, enquanto os mais básicos, Neossolos e o Perfil 5, têm grande influência de lavas ankaratríticas e tufos básicos.

Todos os solos apresentam teores de Fe e Mn disponíveis muito elevados, com teores altos também para os demais microelementos. Entre os metais pesados, há destaque para o $\mathrm{Pb}$, cuja origem pode estar relacionada a minerais potássicos, pela substituição do $\mathrm{K}$ pelo $\mathrm{Pb}$ em função das semelhanças dos dois elementos, ou a uma possível fonte antrópica, ressaltada pela concentração em superfície observada em alguns perfis (Quadro 3).

Na porção mais baixa e mais seca da paisagem, na face norte, encontram-se solos poucos desenvolvidos 
Quadro 3. Atributos químicos dos solos da topossequência na Ilha de Trindade $\begin{array}{llcllllllllllllllllllllllll}\text { Hor. } & \text { Prof. } & \mathrm{pH} & \mathrm{H} & \mathrm{H} & \mathrm{K} & \mathrm{Ca} & \mathrm{Mg} & \mathrm{Al} & \mathrm{H}+\mathrm{Al} & \mathrm{SB} & \mathrm{t} & \mathrm{T} & \mathrm{V} & \mathrm{m} & \mathrm{N} & \mathrm{MO} & \mathrm{C} / \mathrm{N} & \mathrm{Fe} & \mathrm{Mn} & \mathrm{Zn} & \mathrm{Cu} & \mathrm{Pb} & \mathrm{Ni} & \mathrm{Cr} & \mathrm{Cd}\end{array}$

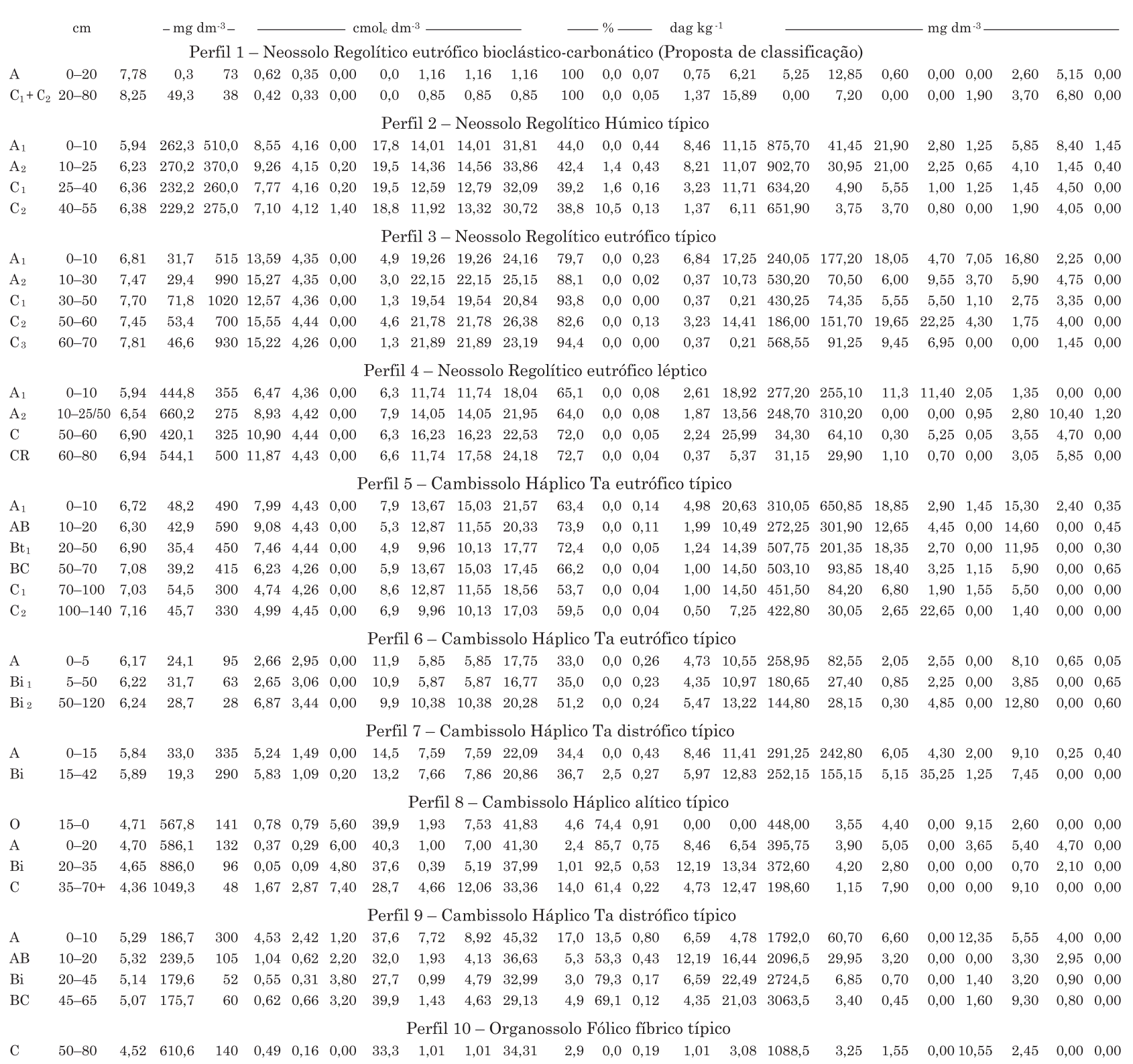

(P1, P2 e P3). Desses, o Perfil 1 apresenta valores mais baixos em nutrientes, o que é explicado pelo material de origem, formado de areias calcárias com pouca contribuição de sedimentos arenosos de rochas vulcânicas subordinadas. Soma-se a essa condição o fato de ser um solo com textura arenosa, o que favorece maior lixiviação. Os demais solos apresentam valores considerados extremamente altos para macronutrientes, especialmente os Perfis 2 e 3, que são desenvolvidos de lavas ankaratríticas. Contribui para este fato o clima mais seco da vertente norte da ilha, que retarda os processos químicos de intemperismo. Em cota aproximadamente $40 \mathrm{~m}$ mais elevada que o P1, encontra-se outro Neossolo (P3), apresentando características distintas dos demais e experimentando uma condição menos sazonal, formado da decomposição de lavas e escórias vulcânicas. Todos os nutrientes são considerados muito altos em relação 
aos valores de referência, em especial o K, o cálcio e o magnésio. Os teores dos metais pesados analisados são considerados baixos para todos os perfis desta classe.

Ribeiro (2003) e Marques (2004, 2007a) encontraram resultados semelhantes em Neossolo Litólico no Arquipélago de Fernando de Noronha, que apresentou elevados valores de CTC e saturação por bases, com predominância de cálcio e magnésio trocáveis no complexo de troca, associados aos altos teores de carbono orgânico $(3,46$ \%) e níveis de $\mathrm{P}$ disponível entre 1.640 e $2.430 \mathrm{mg} \mathrm{dm}^{-3}$. Em Trindade, os valores de $\mathrm{P}$ disponível são também elevados, atingindo cerca de $660 \mathrm{mg} \mathrm{dm}^{-3}$ nos Neossolos. Nunes (1962), por sua vez, encontrou baixos valores de $\mathrm{P}$ e de matéria orgânica em Neossolos da ilha de São Nicolau, mas altos valores de K e CTC. Na ilha do Fogo em um Neossolo Litólico foram observados teores de cálcio e magnésio próximos aos encontrados em Trindade, com matéria orgânica em torno de 1 a 2 dag kg-1, enquanto para um Neossolo Regolítico, o teor de matéria orgânica foi superior (Faria, 1974).

O material orgânico nos solos de Trindade tem baixa a média relação $\mathrm{C} / \mathrm{N}$, e mostra uma distribuição mais uniforme do carbono orgânico (C.O) em quase todos os perfis (Quadro 3), destacando-se nos solos mais desenvolvidos sobre tufos (Cambissolos), enquanto o maior acúmulo do C.O ocorre em áreas protegidas da vertente sul, ambiente mais favorável ao desenvolvimento de Cyathea delgadii (Quadro 3).

Esta matéria orgânica acumulada em maiores altitudes é responsável pela maior acidez potencial $(\mathrm{H}+\mathrm{Al})$ e baixa saturação por bases (V) dos solos, mesmo nos perfis com elevado teor de cátions básicos. A acidez da matéria orgânica influencia também a elevada saturação por $\mathrm{Al}$ observada nos P8 (com caráter alítico) e em P9, embora o teor de Al trocável seja elevado nesses solos, a complexação pela matéria orgânica possa reduzir sua fitotoxidez e inviabilizar a formação de oxi-hidróxidos de Al (Quadro 3).

O Perfil 5 da topossequência é originado de tufos e lavas ankaratríticas e possui altos teores de nutrientes, em especial $\mathrm{K}$, Ca e Mg, sendo o perfil que apresentou os maiores teores de $\mathrm{Mn}$ e $\mathrm{Ni}$, indicando a influência máfica. Os teores de $\mathrm{P}$ disponíveis, comparados aos demais solos estudados, são mais baixos (35 a $48 \mathrm{mg} \mathrm{dm}^{-3}$ ), enquanto os valores de $\mathrm{K}$ são os mais elevados (300 a $590 \mathrm{mg} \mathrm{dm}^{-3}$ ), bem como os micronutrientes Fe e Mn.

Faria (1974) analisou dois perfis de solos comparáveis na Ilha do Fogo e encontrou $\mathrm{pH}$ entre 6,9 e 7,2, com CTC mediana a alta e Ta. A quantidade de $\mathrm{Ca}$ e $\mathrm{Mg}$ é muito superior à encontrada em Trindade, enquanto o K quase inexiste, com baixo teor de matéria orgânica inclusive nos horizontes superficiais. Nunes (1962) investigou quatro solos considerados Cambissolos (com cerosidade) na ilha de São Nicolau e encontrou altos valores de CTC e pH $(7,4$ a 9,3$)$, todos com argilas de atividade alta, com valor de matéria orgânica variáveis no horizonte $\mathrm{A}$ (até 2 dag $\mathrm{kg}^{-1}$ ). Tal diferença do Perfil 5 de Trindade pode estar associada ao material de origem, uma vez que os solos estudados por esses autores apresentavam uma litologia vulcânica mais ácida, distinta, portanto, das lavas básicas de Trindade.

Em altitude mais elevada (448 m), encontra-se o único platô estável da ilha e, com isso, maior grau de intemperismo. O Cambissolo (P6) originado de tufos porosos e fonolitos é um dos solos que apresenta os menores teores de nutrientes, ainda que considerados altos comparados aos valores de referência para solos continentais. A acidez trocável e a saturação por $\mathrm{Al}$ são nulas, mas a acidez potencial é considerada muito elevada. Esse solo demonstra semelhança com os Andissolos (FAO, 1998) descritos por Breemen \& Buurman (1998) em razão da alta retenção de P (P rem), certo escurecimento no $\mathrm{Bi}$ e início de uma agregação forte. Os valores de Prem indicam que apenas os perfis P5 e P7 são solos com alta capacidade de adsorção de $\mathrm{P}$ em razão do material de origem que possui mineralogias ricas em óxidos de $\mathrm{Fe}$ e $\mathrm{Al}$ (Clemente, 2006).

Na parte superior da ilha, na face voltada para o Sul, encontram-se Cambissolos distróficos (perfis 7, 8 e 9), sendo os solos típicos das maiores altitudes onde o clima mais úmido e frio faz com que a vegetação predominante seja mais exuberante, apesar dos baixos teores de grande parte dos nutrientes (Quadro 3). Em função da atividade ornitogênica atual (ninhais de aves) verificada nas imediações dos perfis $\mathrm{P} 4$ e P8, e em menor proporção da riqueza em apatitas, anomalia comum em rochas alcalinas. Os teores de $\mathrm{P}$ disponível são muito elevados (até $1049 \mathrm{mg} \mathrm{dm}^{-3}$ ) e os demais nutrientes, embora mais baixos, ainda são considerados altos em relação a valores de referência para solos de altitude no Brasil (Benites, 2002). A atividade ornitogênica parece ser a principal razão para os valores tão elevados de $\mathrm{P}$, já que a ilha serve de abrigo a importante população de aves, inclusive uma espécie endêmica (Petrel de Trindade). Nesse caso, os solos estariam sofrendo fosfatização ornitogênica por um processo de longa duração (Schaefer et al., 2008).

Marques (2003, 2007b), estudando os Cambissolos de Fernando de Noronha, mostrou um perfil classificado como Cambissolo Háplico Tb distrófico, semelhante aos perfis 7 e 9 de Trindade. São de baixa fertilidade natural e com baixos valores para a soma e saturação por bases e altos níveis de Al, apresentando caráter alumínico nos horizontes subsuperficiais. Tais diferenças podem estar associadas aos distintos materiais de origem. Possuem altos teores de carbono orgânico até $90 \mathrm{~cm}$ de profundidade, e o P disponível, com valores muito altos nos dois primeiros horizontes, decresce drasticamente em profundidade, sugerindo uma origem predominantemente orgânica.

O Organossolo apresentou reação ácida, com valores altos de $\mathrm{P}$ e $\mathrm{K}$ e baixos de $\mathrm{Ca}$ e $\mathrm{Mg}$, com elevada acidez potencial. Vale acrescentar que é esperado para 
esse solo, como referenciado na sua caracterização física, conteúdo expressivo de alofanas, o que pode estar influenciando na produção dessa acidez potencial. Foi o perfil que apresentou maiores teores de Fe, depois do P9, e menores teores de microelementos, exceto $\mathrm{Pb}$. Encontra-se em condição de maior umidade e acúmulo de matéria orgânica na liteira, cujo material ainda se encontra inalterado, proveniente de floresta de Cyathea Delgadii e Myrsine floribunda.

Faria (1974) mostrou resultados de horizontes superficiais de Organossolos na ilha do Fogo, onde o $\mathrm{pH}$ oscilou entre 6,5 e 7,6, a matéria orgânica com níveis de 3,1 a 7,7 dag $\mathrm{kg}^{-1}$, CTC elevada, levando em conta a argila e matéria orgânica. O Ca e Mg são bem expressivos, enquanto K é baixo. Os elevados teores de carbono orgânico mostram que as condições ambientais não são favoráveis à decomposição da matéria orgânica, sobretudo pela baixa produção da biomassa da vegetação. Esses resultados corroboram com os dados obtidos em Trindade, tendo este perfil o pH mais ácido e o maior teor de carbono orgânico nos horizontes superficiais, no contexto de materiais fibricos. A acumulação desse material e a sua não decomposição podem ser resultantes da baixa atividade microbiana e da formação de complexos estáveis de $\mathrm{Al}-\mathrm{MO}$, mais resistente à oxidação, como relatado por Benites (1998) referindo-se a solos tropicais e subtropicais. A complexação do Al pela matéria orgânica pode ser a responsável pela a ausência da acidez trocável.

\section{CONCLUSÕES}

1. A diversidade de solos na ilha da Trindade é profundamente relacionada com as variações do material de origem e da posição geomorfológica/ altimétrica. De maneira geral, os solos em cota de até $400 \mathrm{~m}$ possuem alta fertilidade natural, grau de intemperismo pouco acentuado e valores muito elevados de $\mathrm{Pe} \mathrm{Ca}$, em parte atribuídos a atividade da avifauna, atual ou pretérita.

2. Na face sul da Ilha, mais fria e úmida, os vales estreitos e as encostas íngremes são recobertas de vegetação mais exuberante, com grande acúmulo de MO mesmo em declives acentuados, formando Organossolos e outros solos com acúmulo de material orgânico fíbrico nas cotas mais altas. São solos mais ácidos e pobres em nutrientes, mas com teores de $\mathrm{P}$ muito elevados.

3. Na face norte da ilha, onde predominam condições semiáridas ou tropicais secas, os solos são mais rasos, mais ricos em nutrientes e mais erodidos, predominando Neossolos Litólicos e Neossolos Regolíticos, associados com afloramentos de rochas.

4. A ilha da Trindade apresenta solos com características peculiares, não contempladas no SiBCS
(Embrapa, 2006), sugerindo um caráter endêmico, destacando-se na priorização para a criação de unidade de conservação em âmbito federal, conjuntamente com os endemismos botânicos registrados (Alves, 1998) e com a presença de floresta monodominante de samambaias gigantes (Cyathea sp.), única remanescente no Atlântico Sul.

\section{AGRADECIMENTOS}

À Marinha do Brasil (Navio Hidrográfico Sirius e Graça Aranha), pelo apoio no transporte e permanência no POIT durante três campanhas de campo na Ilha, e ao apoio do CNPq na concessão de bolsas de estudo.

\section{LITERATURA CITADA}

ALMEIDA, F.F.M. Geologia e petrologia da Ilha da Trindade. Rio de Janeiro, DNPM/DGM, 197p. 1961. (Monografia, 18)

ALMEIDA, F.F.M. As ilhas oceânicas brasileiras e uma hipótese sobre a origem do Atlântico, An. Acad. Bras. Ci., 37:141145,1965

ALMEIDA, F.F.M. A Ilha de Trindade. In: SCHOBBENHAUS, C.; CAMPOS, D.A.; QUEIROZ, E.T.; WINGE, M. \& BERBERT-BORN, M., eds. Sítios Geológicos e Paleontológicos do Brasil. 2000. Disponível em: <http:// www.unb.br/ig/sigep/sitio092/sitio092.htm>

ALVAREZ V., V.H.; NOVAIS, R.F.; BARROS, N.F.; CANTARUTTI, R.B. \& LOPES, A.S. Interpretação dos resultados das análises de solos. In: In: RIBEIRO, A.C.; GUIMARÂES, P.T.G. \& ALVAREZ V., V.H., eds. Recomendação para o uso de corretivos e fertilizantes em Minas Gerais - $5^{\text {a }}$ Aproximação. Viçosa, MG, CFSEMG, 1999. p.25-32.

ALVES. R.J.V. Ilha da Trindade \& Arquipélago Marin Vaz: Um ensaio geobotânico. Rio de Janeiro, Serviço de Documentação da Marinha, 1998. 144p.

ALVES, R.J.V. Flora \& vegetação das Ilhas da Trindade e Martin Vaz (resumo). In: ALVES, R.J.V. \& CASTRO, J.W.C., orgs. Ilhas Oceânicas Brasileiras - Da pesquisa ao manejo. Brasília, Ministério do Meio Ambiente, 2006. p.254-255.

BATISTELLA, M. Cartografia Ecológica do Arquipélago de Fernando de Noronha. São Paulo, Universidade de São Paulo, 1993. 236p. (Tese de Mestrado)

BENITES, V.M. Caracterização química e espectroscópica da matéria orgânica e suas relações com a gênese de solos na Serra do Brigadeiro, Zona da Mata Mineira. Viçosa, MG, Universidade Federal de Viçosa, 1998. 123p. (Tese de Mestrado) 
BENITES, V.M. Caracterização de solos e de substâncias húmicas em áreas de vegetação rupestre de altitude. Viçosa, MG, Universidade Federal de Viçosa, 2002. 71p. (Tese de Doutorado)

BOCKHEIM, J.G. Soil endemism and its relation to soil formation theory. Geoderma, 129:109-124, 2005.

BREEMEN, N.V. \& BUURMAN, P. Soil formation. London, Klumer Academic Publishers, 1998. 377p.

CAMPOS, T.F.C.; VIRGENS NETO, J.; SIRIVASTAVA, N.K.; PETTA R.A.; HARTMANN L.A.; MORAES, J.F.S.; MENDES, L. \& SILVEIRA S.R.M. 2005. Arquipélago de São Pedro e São Paulo. Soerguimento tectônico de rochas infracrustais no Oceano Atlântico.Disponível em: <http// www.unb.br/ig/sigep/sitio 002/sitio 002.pdf>

CARDOSO, J.C. Caracterização das principais unidades pedológicas do «esboço da carta dos solos de S.Tomé e Príncipe». Lisboa, Junta de Investigações do Ultramar, 1958. p.21-28.

CLEMENTE, E.P.; SCHAEFER, C.E.; ALBUQUERQUE FILHO, M.R.; OLIVEIRA, F.S.; ALVES, R.J. \& MELO, V.F. Solos "Endêmicos" da Ilha da Trindade. In: ALVES, R.J. \& CASTRO, J.W.C. orgs. Ilhas Oceânicas Brasileiras - Da pesquisa ao manejo. Brasília, Ministério do Meio Ambiente, 2006. p.59-82.

CORDANI, U.G. Idade do vulcanismo do Oceano Atlântico Sul. São Paulo, Instituto de Geociências e Astronomia, 1970. p.9-75. (Boletim IGA, 1)

DEFELIPO, B.V. \& RIBEIRO, A.C. Análise química do solo (metodologia). 2.ed. Viçosa, MG, Universidade Federal de Viçosa, 1997. 26p. (Boletim de Extensão, 29)

EMPRESA BRASILEIRA DE PESQUISA AGROPECUÁRIA EMBRAPA. Centro Nacional de Pesquisa de Solos. Manual de métodos de análise de solo. 2.ed. Rio de Janeiro, 1997. $212 p$.

EMPRESA BRASILEIRA DE PESQUISA AGROPECUÁRIA EMBRAPA. Centro Nacional de Pesquisa de Solos. Manual de análises químicas de solos, plantas e fertilizantes. 3.ed. Rio de Janeiro, 1999b. 370p.

EMPRESA BRASILEIRA DE PESQUISA AGROPECUÁRIA EMBRAPA. Centro Nacional de Pesquisa de Solos. Sistema brasileiro de classificação de solo. 2.ed. Rio de Janeiro, 2006. 323p.

FAO. World reference base for soil resources. Rome, 1998 $109 \mathrm{p}$.

FARIA, F.X. Os solos da Ilha do Fogo (Arquipélago de Cabo Verde) Lisboa, Junta de Investigações Científicas do Ultramar, 1974. 146p. (Ensaios e Documentos, 129)

FAUZI, A.I. \& STOOPS, G. Reconstruction of a Toposequence on volcanic material in the Honje Mountains, Ujung Kulon Peninsula, West Java. Catena, 56:45-66, 2004.

GERARD, M.; CAQUINEAU, S.; PINHEIRO, J. \& STOOPS, G. Weathering and allophane neoformation in soils on volcanic ash from the Azores. Eur. J. Soil Sci., 58:496$515,2007$.
LEMOS, R.C. \& SANTOS, R.D. Manual de descrição e coleta de solo no campo. 3.ed. Campinas, Sociedade Brasileira de Ciência do Solo, 1996. 84p.

LIMA, J.F.W.F. Caracterização e classificação de Neossolos do Arquipélago de Fernando de Noronha. In: CONGRESSO BRASILEIRO DE CIÊNCIA DO SOLO/SOLO: ALICERCE DOS SISTEMAS DE PRODUÇÃO, 29., Ribeirão Preto, 2003. Anais. Ribeirão Preto, 2003. CD ROM.

MARQUES, F.A.; RIBEIRO, M.R.; BITTAR, S.M.B.; LIMA NETO, J.A \& JACOMINE, P.K.T. Caracterísiticas e classificação de Cambissolos e Vertissolos do Arquipélago de Fernando de Noronha. In: CONGRESSO BRASILEIRO DE CIÊNCIA DO SOLO/SOLO: ALICERCE DOS SISTEMAS DE PRODUÇÃO, 29., Ribeirão Preto, 2003. Anais. Ribeirão Preto, 2003. CD ROOM

MARQUES, F.A. Caracterização e classificação de solos da Ilha de Fernando de Noronha (PE). Recife, Universidade Federal Rural de Pernambuco, 2004. 101p. 2004. (Tese de Mestrado)

MARQUES, F.A.; RIBEIRO, M.R.R.; BITTAR, S.M.; TAVARES FILHO, A.N.T. \& LIMA, J.F.W.F. Caracterização e classificação de Neossolos da Ilha de Fernando de Noronha. R. Bras. Ci. Solo, 31:1553-1562, 2007a.

MARQUES, F.A.; RIBEIRO, M.R.R.; BITTAR, S.M.; TAVARES FILHO, A.N.T.; LIMA NETO, J.A. \& LIMA, J.F.W.F. Caracterização e classificação de Cambissolos do Arquipélago de Fernando de Noronha, Pernambuco. R. Bras. Ci. Solo, 31:1023-1034, 2007b.

MILET-MUREAU, M.L.A. Voyage de La Pérouse au tour du mond (1741-1788) Paris, Imprimerie de la Re'publique, Paris, 1797. p.26-29.

NUNES, M. Os solos da Ilha de São Nicolau (Arquipélago de Cabo Verde). Lisboa, Junta de Investigações do Ultramar, 1962. 108p. (Ensaios e Documentos, 94)

PRIOR, G.T. Petrographic notes on the rock specimens collected in the litle Island of Trinidad, South Atlantic, by the Artic Expedition of 1839-1843 under Sir James Clark Ross. Mineral. Magazin J. Mineral. Soc., 22:317-323, 1900 .

RESENDE, M.N. Aplicações de conhecimentos pedológicos à conservação de solos. Inf. Agropec., 11:3-18, 1985.

RICARDO, R.P.; MADEIRA, M.A.V.; BETTENCOUT MEDINA, J.M.; MONTEIRO MARQUEZ, M. \& SANCHES FURTADO, A.F.A. Esboço pedologico da Ilha de S. Miguel (Açores). An. Inst. Super. Agron., 37:275-385, 1977.

RIBEIRO, M.R.; MARQUES, F.A.; BITTAR, S.M.B.; FERRAZ, F.B.; JACOMINE, P.K.T. \& LIMA, J.F.W.F. Caracterização e classificação de Neossolos do Arquipélago de Fernando de Noronha. In: CONGRESSO BRASILEIRO DE CIÊNCIA DO SOLO/SOLO: ALICERCE DOS SISTEMAS PRODUTIVOS, 29., Ribeirão Preto, 2003. Anais. Ribeirão Preto, 2003. CD ROOM

SCHAEFER, C.E G.R.; CLEMENTE, E.P.; OLIVEIRA, F.S. \& MOREIRA, G.F. Solos e geomorfologia da Ilha da Trindade. In: WORKSHOP ILHAS OCEÂNICAS BRASILEIRAS: DA PESQUISA AO MANEJO, 1., 2005, Rio de Janeiro. Anais. Rio de Janeiro, 2005. CD ROM. 
SCHAEFER, C.E.G.R. Brazilian Latosols and their B horizon microstructure as long-term biotic constructs. Austr. J. Soil Res., 39:909-926, 2001.

SCHAEFER, C.E.G.R.; SIMAS, F.N.B.; GILKES, R.J.; MATHISON, C.; COSTA, L.M. \& ALBUQUERQUE, M.A. Micromorphology and microchemistry of selected Cryosols from Maritime Antarctica. Geoderma 144:104-115, 2008.

SCHOBBENHAUS, C.; CAMPOS, D.A.; DERZE, G.R. \& ASMUS, H.E. Geologia do Brasil. Texto explicativo do mapa Geológico do Brasil e da Área Oceânica adjacente incluindo Depósitos Minerais. Escala 1:2.500.000, Brasília, Departamento Nacional da Produção Mineral, 1984. 501p.
SOARES, L.C. As ilhas oceânicas. In: AZEVEDO, A., ed. Brasil, a terra e o homem, bases físicas. São Paulo, Companhia Editora Nacional, 1964. v.1. p.341-378.

WAGNER, W.L.; HERBEST, D.R. \& SOHMER, S.H. Manual of the flowering plants of Havaí. Havaí, University of Havaí Press, 1991. 2v. p.1854.

WEAVER, B.L. Geochemical of the highly - undersaturated ocean island basalt suites from the South Atlantic Ocean Fernando de Noronha and Trindade. Contrib. Geol. Petrol., 105:502-515, 1990.

VELTHEIM, R.V. Geologia da Ilha da Trindade. Relatório prévio da Expedição João Alberto à Ilha da Trindade. Rio de Janeiro, 1950 